ppi $201502 Z U 4645$

Esta publicación cientifica en formato digital es continuidad de la revista impresa ISSN-Versión Impresa 0798-1406 / ISSN-Versión on line 2542-3185Depósito legal pp

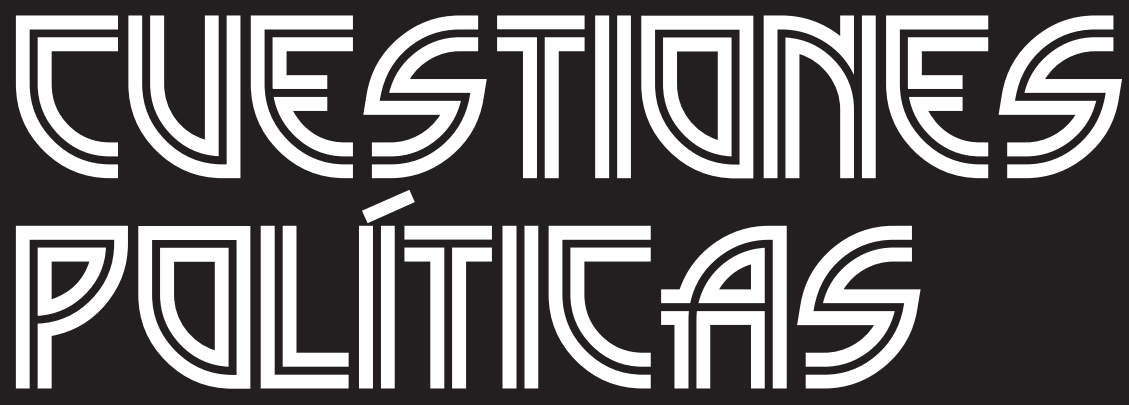

Instituto de Estudios Políticos y Derecho Público "Dr. Humberto J. La Roche' de la Facultad de Ciencias Jurídicas y Políticas de la Universidad del Zulia Maracaibo, Venezuela
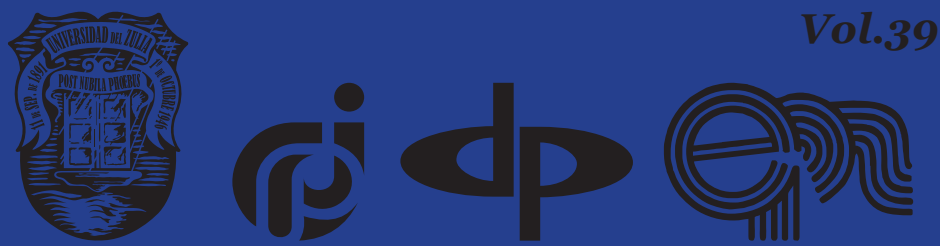


\title{
Rules of criminal liability for corruption offences and their prevention
}

\author{
DOI: https://doi.org/10.46398/cuestpol.3968.46
}

\author{
Borovyk Andrii * \\ Vartyletska Inna ** \\ Vasylenko Yuliia *** \\ Patyk Andrii $* * * *$ \\ Pochanska Olena $* * * *$
}

\section{Abstract}

The objective of the article is to conduct a comparative legal study of Ukrainian and international standards of criminal liability for corruption offences and their prevention. The research methodology includes the following methods: system-structural method, formal-dogmatic method, historical method, grouping method, comparative-legal method, legal modeling method and others. As a result, the peculiarities of anti-corruption regulatory-legal provisions and police practice in the states analyzed are clarified, with the selection of relevant positive and negative trends, principles of construction of anti-corruption policy, specificity of the conceptual apparatus, etc. Emphasis is placed on the need to further harmonize Ukrainian legislation with international agreements and the practice of their implementation. It is concluded that negative trends in foreign countries have been found to be the result of non-compliance with relevant commitments to combat and prevent corruption.

Keywords: criminal offences ofcorruption; international anti-corruption standards; Ukrainian experience in the fight against corruption; criminal liability; crime prevention.

* PhD in Law, Associate Professor, Corresponding Member of the Academy of Economic Sciences of Ukraine, Professor of the Department of Criminal Law and Justice of Academician Stepan Demianchuk International University of Economics and Humanities. ORCID ID: https://orcid.org/oooo-00031834-404X. Email: mail@megu.edu.ua

** PhD in Law, Associate Professor, Professor of Criminal Law Department of the National Academy of Internal Affairs. ORCID ID: https://orcid.org/oooo-0002-3447-0567. Email: kkpnavs@ukr.net

*** PhD in Law, Associate Professor at the Department of Criminal Law, Criminal Procedure and Criminalistics of Kyiv Institute of Intellectual Property and Law of the National University «Odessa Law Academy». ORCID ID: https://orcid.org/oooo-0002-4037-8257. Email: Kiev_iiv@onua.edu.ua

**** PhD in Law, Head of the Research Laboratory for Forensic Support and Forensic Examination of the Educational and Scientific Institute №2 of the National Academy of Internal Affairs. ORCID ID: https://orcid.org/oooo-0o02-3259-454X. Email: NDLPEKZ@ukr.net

***** Associate Professor of the Department of Legal Support of Economic Activity of the Faculty №6 of Kharkiv National University of Internal Affairs. ORCID ID: https://orcid.org/oooo-0003-3953-8660. Email: epochanskaya@gmail.com 


\section{Normas de responsabilidad penal por delitos de corrupción y su prevención}

\section{Resumen}

El objetivo del artículo es realizar un estudio jurídico comparado de los estándares ucranianos e internacionales de responsabilidad penal por delitos de corrupción y su prevención. La metodología de investigación incluye los siguientes métodos: método sistema-estructural, método formal-dogmático, método histórico, método de agrupamiento, método comparativo-legal, método de modelado legal y otros. A modo de resultados se aclaran las peculiaridades de las disposiciones normativolegales anticorrupción y la práctica policial en los estados analizados, con la selección de tendencias positivas y negativas relevantes, principios de construcción de la política anticorrupción, especificidad del aparato conceptual, etc. Se hace hincapié en la necesidad de armonizar aún más la legislación ucraniana con los acuerdos internacionales y la práctica de su aplicación. Se concluye que se ha comprobado que las tendencias negativas en países extranjeros son el resultado del incumplimiento de los compromisos pertinentes para combatir y prevenir la corrupción.

Palabras clave: delitos penales de corrupción; normas internacionales anticorrupción; experiencia ucraniana en la lucha contra la corrupción; responsabilidad penal; prevención del delito.

\section{Introduction}

The article presents a comparative legal study of national and foreign standards of criminal liability for corruption offenses and their prevention. Performing a comparative legal study of national standards of criminal liability for corruption offenses and their prevention will allow:

- firstly, to understand the degree of regulation of relevant criminal law and criminological provisions at the level of individual States.

- secondly, to assess the extent to which the legislators of individual countries have taken into account the requirements of international and European anti-corruption conventions, treaties, protocols, directives, etc.

- thirdly, to find out the features of anti-corruption regulations and law enforcement practices in the analyzed countries, to highlighting the relevant positive and negative trends, the principles of establishing anti-corruption policy, the specifics of the conceptual apparatus, etc. 
It is necessary to note that in some cases Ukraine implement the foreign practice inadequately, ambiguously and almost mechanically (verbatim) borrows conventional provisions.

In our opinion, doctrinal definitions of corruption criminal offenses can only be of secondary importance, as the current law of Ukraine on criminal liability directly determines the format of such offenses.

Unfortunately, those few works of domestic forensic scientists dedicated to this issue contain just several provisions on criminal offenses related to corruption., None of them contain at least a general concept of this type of offence or define their characteristics and types. There are currently no comprehensive scientific studies on this topic, and the existing scientific publications on this issue do not reveal the essence of "criminal offenses related to corruption".

\section{Methodology}

The choice of research methods is determined by the subject of the research. A set of methods of both general and special scientific knowledge was used. The study is based on such principles of dialectical cognition as historicism, comprehensiveness, objectivity, specificity, determinism, etc.

Such logical methods as analysis, synthesis, abstraction, generalization, deduction, induction, analogy, etc. were widely used within the article.

System and structural method, which assumes that all phenomena are considered as elements of systems, allowed to consider criminal responsibility as a component of the system of legal measures to combat corruption.

Formal and dogmatic method allowed to analyze the norms of the current legislation of Ukraine and some countries of the world, which establish criminal responsibility for corruption offences.

Historical method helped to trace the dynamics of the development of anti-corruption legislation of some countries of the world.

Clustering method was applied for identifying conceptual foundations of anti-corruption legislation of foreign countries as well as generalized models of corruption (based on the historical and cultural principle).

Using a comparative legal method, the rules governing the prosecution of corruption offenses in Ukraine and in some countries of the world were compared.

Legal modeling method made it possible to substantiate the relevant conclusions and proposals. 
Borovyk Andrii, Vartyletska Inna, Vasylenko Yuliia, Patyk Andrï y Pochanska Olena Rules of criminal liability for corruption offences and their prevention

\section{Literature Review}

The issue of liability for corruption offences is the topic of scientific works of a number of foreign and domestic scientists. For example, Meyer et al., (2012) considered some problems of corruption in the USA. In particular, they investigated legal framework for fighting this negative phenomenon, provided us with the definition of "bribery", "public official" and described the consequences of corruption on different levels.

The same problem was the topic of investigation by Mcinerney (2002). He studied federal legal acts regulating the issue of bribery, namely the Foreign Corrupt Practices Act and the Federal Bribery Statute. Regulation of bribery on the State level was also the part of his investigation.

The issue of criminal liability for corruption offences of legal entities was examined by Meyer et al., (2014). The scholars tried to find out to what extent the companies can be held liable for corruption offences committed by their employees. They also studied the measures that should be undertaken by the companies for corruption prevention and their responsibility for insignificant adoption of these measures. To do this the authors studied the relevant legislation of England and the Netherlands.

Bribery and corruption in Singapore were studied by Chan and Ling (2020). They state that this country shows no tolerance towards corruption and the problem of corruption is regulated by a number of legal acts, namely by the Penal Code, the Prevention of Corruption Act, Corruption, Drag Trafficking and other serious Crimes Act, etc. They also investigated law enforcement and police activities in this sphere, as well as the peculiarities of investigation of corruption offences.

The modern approaches to fighting corruption in Russia were studied by Vorontsov et al., (2018); Iran's criminal policy regarding economic corruptions was examined by Ardestani (2017), legislative regulation of the peculiarities for bringing employees for responsibility for committing corruption or corruption-related offense in Ukraine was investigated by Podorozhnii et al., (2020).

\section{Results and Discussion}

Ukraine has been building a law-based State on the example of the European community, in which an individual, his (her) life and health, honor and dignity, inviolability and security are the greatest social values (Kyslyi et al., 2020). That is why studying foreign experience in corruption preventing and fighting this negative phenomenon is of the utmost importance. 
Scholars emphasize that foreign experience is characterized using various methods, strategies, and techniques to combat corruption that are effective in their country (e.g., Sweden, Singapore and Germany), but there are no universal methods to combat this phenomenon, although there are principles that are effective in the respective State (Kuptsova and Riutov, 2017).

Finland, Denmark, New Zealand, Iceland, Singapore, Sweden, Canada, the Netherlands, Luxembourg, Norway, Australia, Switzerland, the United Kingdom, Austria, Israel, the United States, Chile, Ireland, Germany and others are the countries that have created an effective anti-corruption mechanism (although each of these countries has its own peculiarities in the organization of anti-corruption activities, they have a common denominators: efforts to organize active counteraction to corruption; creation of an appropriate legal framework; involvement of public organizations in combating corruption) (Topchii et al., 2016). In fact, a similar list is given by other scholars, noting that the methods of combating corruption in foreign countries are quite diverse - from the formation of effective anti-corruption legislation to the promotion of law-abiding high moral types of employee behavior (Hotyzheva, 2018).

One can often find a number of corruption offenses in the national legislation of foreign countries, among which the most serious are: bribery of officials; bribery in private business; influence trade; fraud; stealing; abuse of office; illegal enrichment and money laundering (Council of Europe, 2014). It should be noted that the concept of "Corruption Criminal Offenses" and its derivatives (including "corruption") are widely used in the criminal law of a number of foreign countries, including the post-Soviet ones. For example, the Penal Code of the Republic of Azerbaijan (Law no. 787-IQ/1999 of December 30) provides for liability for "corruption offences and other offences against the interests of the service" (Articles 308-3143); the Penal Code of the Republic of Kazakhstan (Law no. 226-V/2014 of July 3) provides for the liability for "corruption and other criminal offenses against the interests of the civil service and public administration" (Articles 361 - 371). The Penal Code of the Kyrgyz Republic (Law no. 985-XV/2016 of December 22) distinguishes between "corruption and other crimes against the interests of the State and municipal service" (Chapter 44 of the Special Part) and directly "corruption" (Article 319) as a crime. The Penal Code of the Republic of Moldova (LAW no. 985-XV/2002 of April 18) directly enshrines passive (Article 324) and active (Article 325) corruption among the crimes against the proper order of work in the public sphere (Chapter $\mathrm{XV}$ of the Special Part), as well corruption crimes in the private sector as a separate type of crime (Chapter XVI of the Special Part).

As for the classification of anti-corruption foreign legislation, it will be difficult to do, as the degree, form and level of regulation of anti-corruption 
activity and prevention of corruption differ in each country (even in the case of economic and political alliances such as the EU). They depend on the existence of specific laws to prevent (and / or counter) corruption or the absence of such laws, overwhelming focus on corrupt official (bribe-taker, public official) or the person who gives bribes, assigning responsibility for acts of corruption directly on natural persons of both on natural persons and legal entities (corporations), corruption prevention definitions enshrined in public service laws or their enshrinement mainly in bylaws, priority of corruption prevention or fighting the corruption, focus on foreign corruption instead of the corruption on the national level, etc.

For example, the Federal Law on Corruption Abroad of 1977 (USA), the Law on Corruption of Foreign Officials of 1988 (Canada), and the Law on Bribery of 2010 (Great Britain) are widely discussed in the legal literature due to their effectiveness. There are a number of anti-corruption legal acts in Singapore, which is one of the least corrupt countries in the world: The Penal Code, the Prevention of Corruption Act, Corruption, Drag Trafficking and other serious Crimes Act, etc.

The report "Anti-corruption trends and changes in 2019" (Chambers and Partners, 2019) states that in recent years, many countries:

- firstly, adopted new anti-corruption legislation or improved existing laws, in particular:

a) in 2018 India amended the Act on Corruption Prevention, expanding the responsibility for those who bribe and for public bribery of companies; just civil servants who received bribes were persecuted before then.

b) in 2019 Italy improved anti-corruption legislation by increasing penalties for individuals and companies for some corruption criminal offences and expanding the meaning of the term "foreign civil servant".

c) in 2018 Russia passed laws that provide prosecutors with new means to combat corruption, allow courts to freeze the assets of companies under investigation for corruption offences, up to the maximum amount of any potential fine (the law also provided companies with so-called protection from prosecution for bribery, if they facilitate the detection or investigation of bribery or prove that they were bribed);

- secondly, strengthened international cooperation, as well as cooperation between domestic law enforcement agencies, for example:

a) The United Kingdom, according to the United States model, passed in 2014 the Law that defer prosecution under 
agreements, under which the prosecutor has the right to defer criminal prosecution in exchange for the consent of the defendant (British Bank) to comply with certain requirements (in particular, pay fines, carry out corporate reforms, cooperate with the investigation); Canada did so in 2017;

b) In 2018, the United States passed the Law on the Use of Updated Legal Foreign Data (CLOUD Act), which allowed the US government to access data stored in foreign countries, and vice versa.

Note that the conceptual foundations of anti-corruption legislation of foreign countries, according to some scholars, should be considered the presence of:

1) specialized anti-corruption bodies (for example, in Italy it is the Office of Investigation - Antimafia, in Singapore - Bureau for Investigation of Corruption, in France - Corruption Prevention Service, Central Chamber of Accounts, Central Office for punishment of financial violations in the financial sphere, Central Directorate of General Information).

2) legal framework for combating and preventing corruption (for example, in Finland, anti-corruption rules do not primarily define the type of crime, but a specific area of activity, hence corruption is prevented at the stage of its emergence; in Belgium, the emphasis is on clarifying lawful conduct and anti-corruption standards; Romania has had the Law on the prevention, detection and punishment of corruption since. 2000).

3) a) national programs, strategies, doctrines (for example, Poland has approved the State program "Anti-Corruption Strategy", while in Slovakia there is a "National Anti-Corruption Program").

b) legislation to combat conflicts of interest in the public service (e.g. Spain passed the Law against the use of members of the government and senior government officials for personal purposes (codes of professional ethics) in 2006; the US "Code of Ethics for Civil Service" has defined the moral standards for officials since 1958; Spain adopted the Code of Ethics for Civil Servants in 2007)'

c) criminal liability of legal persons for corruption offenses (for example, in Switzerland such liability has been introduced since 2004, in Montenegro - since 2005).

d) prohibition on lobbying (for example, the US Honest Leadership and Open Government Act of September 14, 2007 enshrines the order of the disclose of information about lobbying and funding, 
Borovyk Andrii, Vartyletska Inna, Vasylenko Yuliia, Patyk Andrii y Pochanska Olena
730 Rules of criminal liability for corruption offences and their prevention

limits gifts to members of Congress and their staff, provides for mandatory disclosure of their costs), etc. (Fadieiev, 2015).

Taking into account the experience of different States Nevmerzhytskyi (2009) and Voloshenko (2018) offer the following generalized models of corruption based on the historical and cultural principle:

1) Asian.

2) African.

3) Latin American.

4) Western European.

As for the EU States, scholars divide them into three groups according to the level of corruption:

- the "Corrupt South" (southern Catholic countries) - Italy, Spain, Greece, Belgium, Portugal, France, etc.

- the "Pure North" (northern Protestant countries) - Denmark, Sweden, the Netherlands, Finland, etc.

- Countries that are at a level of corruption between the two previous groups - Great Britain, Germany, Austria, Luxembourg, Ireland, etc., (Pujas and Rhodes, 1999).

In general, according to Buryak (2020), the success of the fight against corruption in the EU countries depends not only on the presence or absence of anti-corruption infrastructure in the country, but on economic, historical, cultural and many other factors that usually lie outside the legal area. The image of a high-ranking official in the public consciousness is identified with a person who performs important functions - pursues State policy and serves the population. Corruption is perceived by the governments of these countries as a serious problem of national security. At the same time, corruption is seen as an internal and external threat. It is quite important that efforts to limit corruption in these countries are, as a rule, are institutionalized and impressive in scale.

In this regard the following should be noted: firstly, Organization for Economic and Social Development (OECD), and in particular its AntiCorruption Network for Eastern Europe and Central Asia, is one of the most among the number of organizations for cooperation in preventing and combating corruption offenses; secondly, the reports of international experts have a significant impact on the attractiveness of countries for foreign investors (for example, this is a positive assessment of Ukraine provided by the experts of the Council of Europe (2014), UN, OECD and other organizations, which is especially important in the context of our country's intention to integrate into the European Union). 
At the same time, non-fulfillment of the relevant obligations to combat and prevent corruption is the negative trends in foreign countries. For example, GRECO states that not every CoE Member State adheres to the implementation of anti-corruption recommendations (in particular, negative conclusions were made in 2019 regarding Germany, to which the «non-compliance procedure» has been applied, as well as with respect to the Republic of Belarus, Hungary, Luxembourg, Ireland, Turkey, Romania, Portugal, the Czech Republic, Denmark, France, Northern Macedonia, and Austria).

As for Ukraine, the national standards of criminal liability for corruption offenses and their prevention are represented by the provisions of the relevant domestic laws and regulations, as well as implemented international (including European) conventions, treaties, protocols, and other documents. As a rule, the official websites of State bodies, institutions and enterprises publish a general list of domestic (Constitution of Ukraine, relevant laws of Ukraine, codes, decrees of the President of Ukraine, resolutions and orders of the Cabinet of Ministers of Ukraine, departmental documents, etc.) and international (relevant conventions, agreements, statutes, etc.) anticorruption regulations, among which there are documents that are directly related to combating and preventing corruption offenses.

In our opinion, the provisions of the Criminal Code of Ukraine and the Law of Ukraine "On Corruption Prevention" are of fundamental importance for accountability and prevention of corruption offenses. The National Agency for Corruption Prevention annual national reports on the implementation of the principles of anti-corruption policy are also important, as they are the main documents that summarize all data on the state of corruption in the country.

\section{Conclusion}

Summarizing the above, it is necessary to agree with Holovkin and Timchenko (2015) and conclude that the new system of anti-corruption legislation is in the process of being adopted in Ukraine, due to the passing the laws of Ukraine on the cleansing of power, prevention of corruption, the National Anti-Corruption Bureau of Ukraine, the Prosecutor's Office of Ukraine, the State Bureau of Investigation, etc., and is "the beginning of a profound reform of the system of anti-corruption activity in Ukraine". At the same time, in today's context, the formation of the legislative and institutional framework for the development and implementation of state anti-corruption policy is not fully completed in Ukraine and therec is a need for the further harmonization of domestic legislation with international agreements and their application (Dorokhina and Moroz 2019). 
The strategic direction in the fight against corruption in Ukraine remains its prevention in the form of comprehensive precautionary measures, which include:

- defining a strategy for socio-economic development and administrative reform.

- formation of the ideology of the civil service, i.e. its moral principles and values;

- ensuring the transparency of State power and increasing its social value.

- -improvement of anti-corruption legislation.

- real manifestation of political will.

- $\quad$ specific actions to represent corruption as a risky and unprofitable activity.

- improving the activities of law enforcement agencies, etc.

In the context of political and criminological prevention and counteraction to corruption it is proposed: to change the way the public sector performs its duties due to the principle of integrity in public service; to emphasize the implementation of the political will of government officials; to change the existing approaches that have been formed in the public consciousness regarding the perception of corruption as a common phenomenon; to introduce the system of principles of public life; to increase the level of professionalism of officials; to create opportunities for access by all segments of the population to using the services of private companies through a system of benefits, subsidies for certain categories of citizens; to ensure maximum transparency of election procedures, the activities of officials exclusively in a politically neutral manner, as well as transparency and independence of the media, etc.

\section{Bibliographic References}

ARDESTANI, Azadeh. 2017. "Iran's Criminal Policy Regarding Economic Corruptions”. In: Amazonia Investiga. Vol. 6, No. 11, pp. 168-179.

BURYAK, Kateryna. 2020. "Features of anti-corruption legislation in the countries of the European Union" In: Entrepreneurship, Economy and Law. No. 2, pp. 356-360.

CHAMBERS AND PARTNERS. 2019. Anti-Corruption Trends and Developments in 2019. Available online. In: https://www.dentons.com/ en/insights/alerts/2019/december/16/anti-corruption-trends-anddevelopments-in-2019. Date of consultation 08/01/2020. 
CHAN, Jason; LING, Lee May. 2020. Singapore In: Jonathan Pickworth \& Jo Dimmock "GLOBAL LEGAL INSIGHTS - BRIBERY \& CORRUPTION 2020", 7th edition. Global Legal Group Ltd. London, England.

COUNCIL OF EUROPE. 2014. Basic concepts of anti-corruption activities: textbook. Available online. In: https://rm.coe.int/basic-anti-corruptionconcepts-a-training-manual/16806eedgd. Date of consultation 08/01/2021.

DOROKHINA, Yuliia; MOROZ, Ivan. 2019. Corruption and corruption crimes in Ukraine. Scientific notes of Taurida V.I. Vernadsky National University. Vol. 30, Issue 69, No. 3, pp. 95-100.

FADIEIEV, Aleksandr. 2015. "Conceptual bases for anti-corruption legislation of foreign countries" In: Bulletin of Omsk University. Series "Law". Vol. 20, No. 45, pp. 147-150.

HOLOVKIN, Oleksandr; TIMCHENKO, Serhii. 2015. “The role of the prosecutor in the fight against corruption" In: Bulletin of the Ministry of Justice of Ukraine. Vol. 3, No. 161, pp. 64-72.

HOTYZHEVA, Fatimat. 2018. "Experience in combating corruption in foreign countries and the possibility of its use in Russia" In: International Journal of Applied Sciences and Technologies "Integral”. No. 4, pp. 420-425.

KUPTSOVA, Anna; RIUTOV, Dmitrii. 2017. "Foreign experience in combating corruption” In: Interactive science. Vol. 12, No. 22, pp. 100-102.

KYSLYI, Anatolii; PYSMENNA, Mariia; KOLOMOIETS, Oleksandr; VOLOBUIEVA, Olena; BEZUSYI, Vadym. 2020. "Educational processes of training, retraining and advanced training of private detectives in Ukraine”. In: Cuestiones Políticas. Vol. 38, Núm. 66. Pp. $421-435$, https://doi.org/10.46398/cuestpol.38e.28. Date of consultation: 08/11/2020.

AZERBAIJANI REPUBLIC. 1999. Law no. 787-IQ/1999 of December 30. Penal Code of the Azerbaijani Republicof Available online. In: http:// continent-online.com/Document/?doc_id=30420353\#pos=3487;-43. Date of consultation 08/01/2020.

THE REPUBLIC OF KAZAKHSTAN. 2014. Law no. 226-V/2014 of July 3. Penal Code of the Republic of Kazakhstan. Available online. In: https:// online.zakon.kz/document/?doc_id=31575252\#pos=5108;-45. Date of consultation 08/01/2020.

KYRGYZ REPUBLIC. 2016. Law no. 985-XV/2016 of December 22. Penal Code of the Kyrgyz Republic. Available online. In: http://cbd.minjust.gov.kg/ act/view/ru-ru/111527. Date of consultation 08/01/2020. 
Borovyk Andrii, Vartyletska Inna, Vasylenko Yuliia, Patyk Andrii y Pochanska Olena

REPUBLIC OF MOLDOVA. 2002. LAW no. 985-XV/2002 of April 18. Penal Code of the Republic of Moldova. Available online. In: http://continentonline.com/Document/?doc_id=30394923\#pos=310;-142. Date of consultation 08/01/2020.

MCINERNEY, Thomas F. 2002. "The regulation of bribery in the United States" In: Revue internationale de droit penal. Vol. 73, No. 1-2, pp. 81-107.

MEYER, Bram; ROOMEN, Tessa; SIKKEMA, Eelke. 2014. “Corporate Criminal Liability for Corruption Offences and the Due Diligence Defence: A Comparison of the Dutch and English Legal Frameworks" In: Utrecht Law. Vol. 10, No. 3, pp. 37-54.

MEYER, Joan, DEVANEY, William and TOMCZAK, Peter. 2012. AntiCorruption in the United States. n. d. Global Compliance News. Available online. In: https://globalcompliancenews.com/anti-corruption/anticorruption-in-the-united-states/. Date of consultation 08/01/2021.

NEVMERZHYTSKYI, Yevhen. 2009. Corruption as a socio-political phenomenon. Doctoral Dissertation. I.F. Kuras Institute of Political and Ethnic Studies of the National Academy of Sciences of Ukraine. Kiev, Ukraine.

PODOROZHNII, Yevhen; OBUSHENKO, Nataliia; HARBUZIUK, Kostiantyn; PLATKOVSKA, Oksana. 2020. "Legislative Regulation of Grounds for Dismissal of an Employee for Committing a Corruption or CorruptionRelated Offense”. In: Amazonia Investiga, Vol. 9, Issue 26, pp. 304-310.

PUJAS, Véronique; RHODES, Martin. 1999. "A clash of cultures? Corruption and the ethics of administration in Western Europe". In: Parliamentary Affairs. Vol. 52, Issue 4, pp. 688-702.

TOPCHII, Vasyl; SHKELEBEI, Viktoria; SUPRUN, Tetiana. 2016. Public and legal counteraction to corruption: textbook. UDFS. Irpin, Ukraine.

VOLOSHENKO, Antonina. 2018. State regulatory imperatives to combat systemic corruption in the national economy. Doctoral Dissertation. National Academy of Management. Kiev, Ukraine.

VORONTSOV, S; MAMYCHEV, A; PONEDELKOV, A; MEDVEDEV, V; MAGOMEDKHANOV, R. 2018. "Fighting Against Corruption in Modern Russia: Problems and Prospects" In: Amazonia Investiga. Vol. 7, Issue 14, pp. 322-331. 

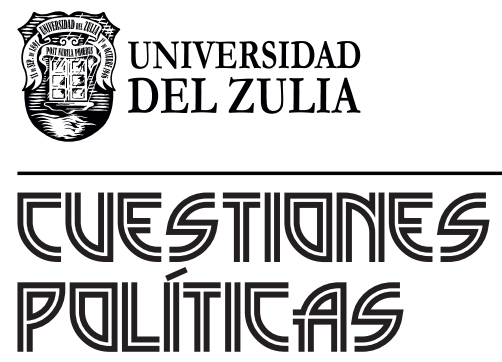

Vol.39 No 68

Esta revista fue editada en formato digital y publicada en enero de 2021, por el Fondo Editorial Serbiluz, Universidad del Zulia. Maracaibo-Venezuela 